PRZEGLĄD RUSYCYSTYCZNY 2020, nr 2(170)

DOI $10.31261 / \mathrm{pr} .7769$

ALEKSANDRA ZYWERT

Uniwersytet im. Adama Mickiewicza w Poznaniu

(D ORCID: http://orcid.org/oooo-00o2-9922-6717

\title{
CODZIENNOŚĆ PRZYSZŁOŚCI, CZYLI PYTANIE O ŻYCIE WIECZNE
}

Codzienność, czyli w obiegowym rozumieniu zwykle to, co w życiu powtarzalne, monotonne, zrutynizowane do tego stopnia, że prawie niezauważalne, zwykle umyka głębszej analizie, albowiem siłą rzeczy jest tłem. Z drugiej jednak strony, jak twierdzi choćby Maurice Blanchot, to właśnie ona, dzięki swojej dwuznaczności polegającej na idealnym wzajemnym przepływie wchłaniania i wyrzucania, jest dla człowieka inspiracją do wprowadzania zmian ${ }^{1}$. W tym kontekście interesujące może być spojrzenie na ów wymiar bytowania w tych utworach współczesnej rosyjskiej fantastyki (autorstwa nie tylko zdeklarowanych pisarzy-fantastów ${ }^{2}$ ), w których kreowana wizja przyszłości jest bezpośrednim przyczynkiem do dyskusji nad prognozowaną kondycją ludzkości w obliczu nieuchronnych zmian cywilizacyjnych (zwłaszcza w obliczu rozwoju technologii cyfrowych). Problem ten (zwłaszcza relacje człowiek-cyberprzestrzeń) bezpośrednio dotyka odwiecznego motywu dążenia człowieka do nieśmiertelności i wpisuje się w krąg zagadnień społecznych omawianych zarówno w literaturze wysokiej, jak i mainstreamowej w kontekście pojęcia „życie codzienne”.

Dotąd, jak podkreślają badacze, najczęstszym „ratunkiem” przed dojmującą świadomością skończoności człowieka była (osiągana dzięki właściwościom rozumu) strategia „usuwania”, „chowania”, „zasłaniania” nieuchronnego, tego, z czym trudno się pogodzić.

${ }^{1}$ M. Blanchot, L'Entretien infini, Éditions Gallimard, Paris 1959, s. 355-366.

2 Jako przykład może służyć Władimir Sorokin, który choć w niektórych swoich utworach posiłkuje się motywami i chwytami charakterystycznymi dla fantastyki, to nie jest zaliczany do grona fantastów. 
„Odkąd odkryto śmierć, społeczności ludzkie nie ustają w poszukiwaniu wymyślnych sposobów na to, by zapomnieć o tym skandalu"3, a nawet więcej - przezwyciężyć go. Powstaje zatem konflikt: z jednej strony biologicznie uwarunkowane, mające swoje źródło w tzw. popędzie życiowym, tłumienie myśli o śmierci, jak wskazuje Max Scheller, pozwala człowiekowi nie tylko przetrwać, ale daje mu poczucie stabilizacji, a nawet szczęścia ${ }^{4}$ i jest (z socjologicznego punktu widzenia) impulsem do tworzenia i rozwoju kultury („Bez śmiertelności nie byłoby historii, nie byłoby kultury - nie byłoby ludzkości" 5 ). Paradoksalnie właśnie śmierć jest gwarantem nieśmiertelności - „gdyby nie świadomość ulotności życia i nieuchronności śmierci, nie byłoby impulsu do tworzenia form nieśmiertelnych, niezniszczalnych"6. Z drugiej - człowiek nie ustaje w wysiłkach, by sprzeciwić się własnej naturze, zwyciężyć w walce z biologią i żyć wiecznie. Rodzi się zatem pytanie: co się stanie, jeśli ten zamiar się powiedzie?

Biorąc pod uwagę, że literatura analizuje lęki społeczne, niebagatelna rola $\mathrm{w}$ procesie analizy tego problemu przypada fantastyce socjologicznej ${ }^{7}$, ale postrzeganej w Rosji (i w ogóle w krajach postkomunistycznych) już nieco inaczej niż przed transformacją ustrojową. O ile do lat 90. XX w. była ona skupiona przede wszystkim na krytyce ustrojów społecznych o charakterze totalitarnym, o tyle później przeorientowała się na zagadnienia globalizacyjne w kontekście postępującego zaniku wszelkich wartości indywidualnych oraz ocenę efektów zmian kulturowych. $\mathrm{W}$ tej chwili bodaj najistotniejszą rolę $\mathrm{w}$ tym kontekście odgrywa cyberkultura ${ }^{8}$ jako forma alternatywnego w od-

3 Z. Baumann, Śmierć i nieśmiertelność, PWN, Warszawa 1998, s. 23.

4 M. Scheler, Śmierć i dalsze życie, w: tegoż, Cierpienie, śmierć, dalsze życie, przeł.

A. Węgrzecki, PWN, Warszawa 1994, s. 91-93.

5 Z. Baumann, Śmierć i nieśmiertelność..., s. 12.

6 Z. Baumann, O sztuce, śmierci i demokracji i o tym jak się one do siebie mają, „Teksty Drugie" 1998, nr 3 (51), s. 203.

7 Fantastyka socjologiczna „za centrum swoich zainteresowań stawia sobie [...] przede wszystkim przewidywania możliwych ksztaltów społeczeństwa za kilkadziesiąt bądź kilkaset lat - opiera się na faktach ogólnie dziś znanych i drogą ekstrapolacji ukazuje, co człowieka może czekać, jeżeli świat będzie zmierzał dalej tą samą drogą". T. Bolanowska, Trudni bohaterowie, trudne powroty, trudne wybory. Kilka uwag of fantastyce socjologicznej, „Literatura i Kultura Popularna” 2006, t. XIII, red. T. Żabski, s. 73.

8 Za czołowego przedstawiciela cyberkultury uważa się Johna Perry'ego Barlowa, który w 1996 roku opublikował w sieci A Declaration of the Independence of Cyberspace (Deklaracja Niepodległości Cyberprzestrzeni), „w której proklamował 
niesieniu do tradycyjnych struktur społecznych i kulturowych sposobu funkcjonowania wspólnoty. Z jednej strony pojawia się perspektywa wirtualnego nie-miejsca łączącego ludzkość całego świata w jeden spójny organizm. Z drugiej ten sam organizm (z uwagi na specyfikę swojego funkcjonowania) ludzi od siebie oddala. Dostatecznie rozwinięta, zapewniająca błyskawiczną komunikację cyberprzestrzeń potencjalnie może zapewnić pewną formę nieskończonego trwania człowieka, ale jednocześnie alienuje go i zabija poczucie „trwałości i przynależności, przywiązania do miejsca i ciepła, jakie daje lokalna wspólnota"9.

Utwory współczesnych rosyjskich pisarzy dostarczają w tym zakresie całkiem sporo materiału do rozważań. Zakładając, że nie dojdzie do bliżej nieokreślonej totalnej katastrofy, po której wszystko trzeba będzie zaczynać od nowa, twórcy ci są w zasadzie zgodni, że ekspansja nowych technologii i lawinowo rosnącej atrakcyjności mediów elektronicznych pogłębi pogrążanie się człowieka w cyberprzestrzeni i doprowadzi (głównie dzięki tejże technologii) do ziszczenia się odwiecznego marzenia ludzkości - osiągnięcia szeroko (bo nie tylko w wymiarze fizycznym) pojmowanej nieśmiertelności. Zalążek tego procesu można odnaleźć w tekstach wykorzystujących elementy cyberpunku ${ }^{10}$, eksponujących zjawisko postępującej symbiozy ciała z maszyną wynikającej z konieczności codziennego funkcjonowania człowieka w otoczeniu nowoczesnych technologii komputerowych.

Doskonałym przykładem są choćby jedne z ostatnich utworów Władimira Sorokina. Poczynając od Dnia oprycznika (День опричника, 2006), poprzez Cukrowy Kreml (Сахарный Кремль, 2008), aż po najnowszą powieść Manaraga (Манарагa, 2017), autor prezentuje świat, w którym normą jest postępujące zjawisko kompatybilności (a co za tym idzie, uzależnienia i podporządkowania) technologii elektronicznej z organizmami biologicznymi. W dwóch pierwszych tekstach świat przedstawiony jest jako dziwaczna hybryda nowoczesności i XVI-wiecznej tradycji z czasów panowania Iwana

stworzenie nowej cywilizacji umysłu w cyberprzestrzeni”. P. Zawojski, Cyberkultura. Syntopia sztuki, nauki i technologii, Wydawnictwo Uniwersytetu Śląskiego, Katowice 2018, s. 9.

9 C. Stoll, Krzemowe remedium. Garść rozważań na temat infostrady, przeł. T. Hornowski, REBIS, Poznań 2000, s. 55.

${ }^{10} \mathrm{O}$ pojęciu cyberpunk zob. np. D. Oramus, $O$ pomieszaniu gatunków. Science fiction a postmodernizm, Trio, Warszawa 2010, s. 73-77. 
Groźnego i tam owo potencjalnie niebezpieczne zespolenie nie jest jeszcze aż tak bardzo widoczne, bo nowinki techniczne (autorami których, co istotne, są Chińczycy ${ }^{11}$ ) albo głównie wspierają oficjalną sferę propagandową, albo służą rozrywce (czasami dość specyficznej, niebezpiecznie dryfującej w kierunku patologii seksualnej, jak opis modyfikacji męskich członków: „Восстает уд мой обновленный, с двумя хрящевыми вставками, с вострием из гиперволокна, с рельефными окатышами, с мясной полною, с подвижной татуировкою [...]. У всех опричных муде обновленное китайскими врачами искусными”"12), ale nie mają znaczącego wpływu na osobowość człowieka.

Ostatnia powieść, utrzymana w konwencji antyutopijnej z jeszcze wyraźniej wyeksponowanymi elementami cyberpunkowymi, jest $\mathrm{w}$ tym kontekście bardziej interesująca, albowiem pojawia się w niej wizja ludzkości, której funkcjonowanie jest uzależnione od technologii - w ludzkie mózgi są wszczepione tzw. elektroniczne pchły, jak je nazywa Sorokin, bez których człowiek nie jest w stanie normalnie funkcjonować. Autor pisze:

Мои умные блохи помогают мне. Их у меня три: красная, синяя, зеленая. Красная - самая важная, она ведает моим психосомо + вписывает меня во время + делает меня умнее; дорогая игрушка, 7-я версия, за сто тысяч новыми прыгнула в варолиев мост моего мозга полгода назад. Синяя, навигационная, пасется в волосах. Зеленая, информационно-коммуникативная, живет в ушной раковине. Мягкими ручными умницами я давно уже не пользуюсь. Весь навороченный блошиный комплекс обошелся мне в полтора годовых дохода. Но благодаря своим блохам я по сей день жив и здоров. К тому же теперь у меня в голове есть ВСЕ. При блошиной помощи я могу прочитать лекцию по новейшей теории Темных Полей, подробно рассказать обо всех известных апокрифических Евангелиях, опровергнуть уравнение неопределенности Шрёдингера при помощи формулы Камеямы или дать исчерпывающий ответ о технологии изготовления умного теста или самих этих блох. Сам же я вряд ли уже смогу помножить 17 на 19 и не

${ }^{11}$ Nieprzypadkowo autorami technologii implantów są Chińczycy. Z jednej strony motyw Chin (obecny w twórczości Sorokina od 1999 roku, a więc pojawienia się powieści Голубое сало) jest konsekwentnie rozwijany w kolejnych tekstach autora. Jednocześnie jest on charakterystyczny dla cyberpunku, w którym, jak pisze Adam Mazurkiewicz, „współistnieją tylko dwie rasy: biała i żółta” i to przedstawiciele tej ostatniej (także dzięki pieniądzom uzyskanym z nielegalnych interesów) odpowiadają za opracowanie technologii i wdrożenie jej na rynkach konsumenckich. Szerzej zob. A. Mazurkiewicz, Z problematyki cyberpunku. Literatura - sztuka - kultura, Wydawnictwo Uniwersytetu Łódzkiego, Łódź 2014, s. 293-294.

12 В. Сорокин, День опричника, Захаров, Москва 2006, s. 198-199. 
вспомню, что такое интерференция. [...] В общем, всему лучшему в поварской жизни я обязан своим блохам: подскажут, предупредят, спасут ${ }^{13}$.

Medycyna (głównie tzw. czarna ${ }^{14}$ ), jak podkreśla pisarz, na kolejnym etapie rozwoju ludzkości będzie się skupiała nie tyle na zwiększaniu możliwości wytrzymałości ciała, ile umysłu. Komfort życia znacząco się zwiększy, bo uwolniony od jakiegokolwiek wysiłku intelektualnego człowiek co prawda nie ucieknie przed śmiercią, ale za życia będzie mógł nieustannie pławić się w przyjemnościach i pogoni za coraz to nowymi wrażeniami. Jednocześnie ta właśnie perspektywa bezstresowego bytowania będzie dla niego największą i najokrutniejszą pułapką. Skazana (na własne zresztą życzenie) na uzależnienie od wsparcia technologicznego, ludzkość trwale zdegeneruje się. W efekcie pojawi się głęboko pogrążone w wybujałym konsumpcjonizmie intelektualnie atroficzne społeczeństwo, które nawet nie zauważy momentu swojego upadku.

Potwierdzenie tej tezy można znaleźć w twórczości Wiktora Pielewina. Między innymi w powieściach Hetm grozy (Шлем ужаса: Креатифф о Тесее и Минотавре, 2005) і Mitość do trzech Zuckerbrinów (Любовь к трём иукербринам, 2014) bezpośrednio jest analizowany problem (od jakiegoś czasu nośnej, bo realizowanej zarówno na gruncie literatury, jak i filmu ${ }^{15}$ ) nieśmiertelności sieciowej. Wizja Pielewina jest tym bardziej przekonująca, że istnieje już przecież portal społecznościowy Eter 9, który na bazie sztucznej inteligencji zapewnia człowiekowi swego rodzaju istnienie nawet po śmierci biologicznej. Zbudowana na podstawie ludzkiej aktywności internetowej świadomość cyfrowa działa nawet po śmierci użytkownika i może kontynuować jego działalność na portalu praktycznie w nieskończoność, a pojawiające się posty (jak stara się przekonywać producent) będą nie do odróżnienia od publikowanych za życia użytkownika ${ }^{16}$.

${ }^{13}$ В.Сорокин, Манарага, АСТ, Москва 2017, s. 25.

${ }^{14}$ Pojęcie „czarna medycyna” zob. A. Mazurkiewicz, $Z$ problematyki cyberpunku..., s. 342-344.

${ }^{15}$ Na przykład powieść Neuromancer (Neuromancer, 1984) Williama Gibsona, wktórej zapis pamięci zmarłego jest wciąż aktywny, filmy Avatar (Avatar, 2009), w którym sparaliżowany komandos „wskakuje” umysłem w biomechaniczne ciało, czy Transcendencja (Transcendence, 2014), w którym główny bohater - Will Caster przenosi swoją tożsamość do komputera, by cieszyć się wiecznym życiem.

${ }^{16}$ Szerzej zob. Ł. Gołąbiowski, Ten portal społecznościowy sprawi, że będziesz „nieśmiertelny”, „Komputer Świat”, 24.08.2015, https://www.komputerswiat.pl/ 
W pierwszym z wymienionych tekstów (ciekawych także ze względu na formę - całość jest skonstruowana w formie internetowego czatu) Pielewin jeszcze ogranicza się tylko do postawienia pytania o potencjalne skutki postępującej symbiozy człowieka z maszyną-monitorem i zaledwie dryfuje w kierunku pesymistycznych koncepcji Jeana Baudrillarda i Clifforda Stolla ${ }^{17}$, podając w wątpliwość sens rozpaczliwej i gorączkowej chęci przekraczania wszelkich granic za cenę utraty własnej cielesności i autentycznej tożsamości. W kolejnym utworze, kontynuującym na płaszczyźnie tematyczno-problematycznej rozważania nad problemem człowiek-cyberprzestrzeń, autor już wyraźnie opowiada się po stronie krytyków korzyści wynikających z używania sieci komputerowych. W centrum uwagi autora znajdują się praktycznie wszystkie interesujące nas nośne i kontrowersyjne trendy współczesnego świata, począwszy od kultu konsumpcji aż po uzależnienie od Internetu (w tym od gier komputerowych, Google i Facebooka). Znacząca rola w ilustracji tego problemu przypada głównemu bohaterowi, Kieszy - hipsterowi, typowemu internetowemu trollowi i miłośnikowi młodziutkich japońskich „siostrzyczek”, który pewnego dnia odkrywa przyszłość - rządzony przez trzech Zuckerbrinów fascynujący i jednocześnie przerażający „brave new World”. Kiesza jest wykreowany na matrixowskiego Neo à rebour. Jest przekonany, że w sieci jest wszystko, a nawet więcej (to niekończący się labirynt dający poczucie nieograniczonej przyjemności, bezkarności i wolności wyboru) i dlatego funkcjonowanie w cyberprzestrzeni nie tylko go w pełni satysfakcjonuje, ale wręcz stanowi sens sam w sobie. Na tym tle z czasem wyraźnie krystalizuje się pytanie o rzeczywistą wartość tzw. sieci. Czy ten ekran, z którym (jak pisze Pielewin) „мы трахаемся, советуемся и интересуемся, какие для нас сегодня будут новости"18, jest upostaciowaniem autentycznej wolności? Bez wątpienia autor (mimo typowo postmodernistycznej konwencji powieści zakładającej między innymi programową rezygnację z analizy kwestii epistemologicznych) jest krytycznie nastawiony do nowego paradygmatu kulturowego. Zdaniem pisa-

aktualnosci/internet/ten-portal-spolecznosciowy-sprawi-ze-bedziesz-niesmiertelny/3jhbqn3 (01.02.2019).

${ }^{17}$ Szerzej na ten temat zob.: A. Zywert, W labiryncie światów umystu, czyli o „Hetmie grozy” Wiktora Pielewina, w: B. Żejmo (red.), Rosja w dialogu kultur, t. II, Wydawnictwo Naukowe UMK, Toruń 2015, s. 393-401.

18 В. Пелевин, Любовь к трем цукербринам, Эксмо, Москва 2014, s. 56. 
rza, Internet to „пульсирующий черный полип” ${ }^{19}$, który jest jednym z największych przekleństw ludzkości, trwale deformującym (a ostatecznie unicestwiającym) człowieka w ogóle. Pielewin pisze:

Мы с рождения подключены к информационному потоку, который промывает наши мозги с таким напором, что там не способна появиться ни одна случайная мысль. [...] Нас всех давно подменили. А мы этого не заметили. [...] Ты есть то, что прокачивают сквозь тебя цукербрины. И никакого другого тебя нет. Это реальность нашей жизни. Ее единственная реальность! ${ }^{\circ}$

Tego rodzaju (ironiczne, ale i boleśnie prawdziwe) stwierdzenia wyraźnie wskazują, że idylliczne wizje wiecznego życia w sieci są mu obce. Zanik rzeczywistych autorytetów na rzecz projektu kulturowego, jakim są różnego rodzaju serwisy społecznościowe, czy też niebezpieczną w swej istocie tendencję do zaniku indywidualności na rzecz „kolektywizmu online” - zjawiska potencjalnie niebezpiecznego, trącącego „cyfrowym maoizmem” (jak to określa Piotr Zawojski za Jaronem Lanierem ${ }^{21}$ ), nie unieśmiertelni ludzkości, lecz ją zabije. Widać to choćby we fragmencie, w którym opisane jest spotkanie bohatera z Batu Karajewem - bytem funkcjonującym wyłącznie w cyberprzestrzeni. Pielewin pokazuje, że zamiana iluzji na immersję prowadzi nie tylko do podważenia wszystkich ukonstytuowanych w zbiorowej świadomości społecznej prawd, aksjomatów, przekonań i światopoglądów, lecz także do podważenia istoty istnienia człowieka w ogóle. W tym kontekście cyberkultura to nie jakościowo nowy, otwarty i synergiczny model kultury, lecz forma opresji wobec ludzkości jako takiej. Warto się nad tym zastanowić, sugeruje autor, zanim przekształcimy się w przykute do łóżek i podłączone do aparatury podtrzymującej życie atroficzne twory, „naturalne interfejsy”, które, co prawda potencjalnie nieśmiertelne, to z człowiekiem nie będą już miały wiele wspólnego.

Zwieńczeniem tego procesu, formą praktycznej realizacji Barlowowskiej Deklaracji Niepodlegtości Cyberprzestrzeni z ideą noosfery Teilharda de Chardin ${ }^{22}$, jest wizja społeczeństwa zaprezentowana

19 Tamże, s. 63.

${ }^{20}$ Tamże, s. 142.

${ }^{21}$ Szerzej zob. P. Zawojski, Cyberkultura..., s. 26-37.

${ }^{22}$ Teilhard de Chardin, jak pisze Piotr Zawojski, w swoim czasie zyskał rangę proroka nowej epoki elektronicznej. Jego idea noosfery (świadomości kolektywnej) zakłada powstanie wspólnoty, w której ramach „ludzie łączą za pośrednictwem monitorów, ekranów i sieci swe umysły, tworząc tym samym zbiorową inteligencję”. Noosfera 
przez Annę Starobiniec w powieści Живущиŭ (2011), w której realizuje się koncepcja całkowitej zmiany porządku społecznego. Cała społeczność funkcjonuje wyłącznie w cyberprzestrzeni i jest podporządkowana (tworząc de facto kolektywną świadomość podłączoną trwale do globalnej sieci komputerowej) Żyjącemu - nieśmiertelnej sztucznej inteligencji. Śmierć biologiczna jest co prawda trwale wpisana w jej bytowanie (tzw. pięciominutowa pauza), ale jest to tylko forma „wymiany ciał” konieczna do zachowania trwałości populacji. Ludzkość przekształcona w rodzaj samoodtwarzającego się organizmu musi liczyć dokładnie trzy miliardy żywych osobników. Obserwowana $\mathrm{w}$ powieści erozja, a w niektórych przypadkach nawet zanik wielu aspektów życia społecznego w połączeniu z koniecznością bezwarunkowego podporządkowania się Żyjącemu sprawia, że wizja Starobiniec w dużym stopniu odpowiada wymogom antyutopii przestrzegającej ludzkość przed pełną integracją z siecią.

Z nieco innej perspektywy codzienność ludzkości uwolnionej od strachu przed śmiercią jest zaprezentowana w utworach, w których postęp technologiczny (a ściślej osiągnięcia „białej” medycyny pozwalającej na stuprocentową powtarzalną regenerację organizmu) umożliwia osiągnięcie stanu fizycznej nieśmiertelności. Jako przykład może służyć choćby nowela Borysa Akunina/Grigorija Czchartiszwilego Happy end (Хэппи-энд, 2004) ${ }^{23}$. Bohaterowie - to starsze jak na owe czasy (ich dzieci mają już ponad sto lat) małżeństwo, które żyje dostatnio i spokojnie w idealnie zbalansowanym, wolnym od trosk życia codziennego, świecie. Idylla ma jednak swoją cenę - w ich życie wkrada się nuda, bo jak mówi mąż (a co znajduje potwierdzenie w słowach jego żony): „от старости никуда не денешься [...]. Всё время повторяем одно и то же, рассказываем друг другу вещи, отлично известные нам обоим. Он прав: всё уже было"24. Sytuacja „przesycenia życiem” - to stan, w którym brak ograniczenia czasem prowadzi do sytuacji, w której jednostka nie jest zdolna doświadczać już żadnych nowych pragnień, a więc jest skazana nawet na coś więcej niż tylko wieczną Schopenhauerowską nudę - jest skazana na cierpienie. W tym kontekście świadomość, że wszystkie warianty urozmaicenia codzienności zostały już przeżyte i pozostaje

nieustannie podlega procesowi samodoskonalenia, w rezultacie czego z czasem powstaje idealne społeczeństwo. Tamże, s. 9.

${ }^{23}$ Nowela jest integralną częścią książki Б. Акунин - Г. Чхартишвили, Кладбщенские истории, КоЛибри, Москва 2006.

${ }^{24}$ Tamże, s. 217. 
tylko kręcić się w kole powtarzalności, może doprowadzić do ostatecznego wniosku: jedynym wariantem ucieczki ze ślepego zaułka życia jest samobójcza śmierć - ostatnia zagadka, wybawienie i akt łaski w obliczu perspektywy wiecznego trwania.

Jeszcze inny wariant zmagania się z życiem wiecznym pojawia się u Dmitrija Głuchowskiego (autora początkowo uznawanego za typowo maistreamowego, choć dziś już wyraźnie ewoluującego w kierunku literatury wyższej) w powieści FUTU.RE (Будyщеe, 2013) opowiadającej o świecie, w którym życie wieczne stało się faktem za sprawą wynalezienia leku potocznie zwanego „serum nieśmiertelności”. W wizji Głuchowskiego technologia nie zajmuje szczególnie eksponowanej pozycji z uwagi na przyjętą przez autora konwencję - swego rodzaju postapokalipsy à rebour. Świat przyszłości, to rzeczywistość, w której zwycięstwo nad śmiercią już się dokonało, nie ma więc sensu przybliżać szczegółów tego procesu. O wiele bardziej interesuje autora ekspozycja rzeczywistej jakości życia ludzi niż drobiazgowych opisów nowinek technicznych. Ziemski glob jest podzielony na zajmujące (jak w choćby w przypadku Europy) połowę kontynentu państwa-miasta molochy, w których poza garstką bogaczy (oczywiście związanych z ogromnymi korporacjami) lwia część społeczeństwa mieszka w nieprawdopodobnej ciasnocie i bez nadziei na polepszenie warunków bytowania: ${ }^{25}$

\begin{abstract}
мой блок. От пола до потолка - двадцатиметровой высоты оранжевые стены поделены на ровные квадратики, в каждом - дверка; к стене прикручена решетка из лестниц и трапов: вход в каждый жилой куб - отдельный, снаружи. [...] в кубе размером два на два на два [...]. Одна из стен - та, что напротив койки, - вспыхивает и становится окном от пола до потолка; за ним - мои любимые холмы, и небо, и облака. Все фальшивка, но я вырос на суррогате ${ }^{26}$.
\end{abstract}

Kontakty międzyludzkie są ograniczone do minimum, bo łatwiej i szybciej jest porozmawiać z robotem, albo hologramem (jak w scenie zakupów w sklepomacie). Ściśnięci, zagonieni, zmęczeni ludzie koją nerwy alkoholem i narkotykami:

Я прикладываюсь к бутылке, потом выдавливаю из упаковки последнюю сонную таблетку, кладу в рот, умещаюсь на койке и рассасываю шарик, глу-

${ }^{25} \mathrm{~W}$ niektórych obrazach Głuchowski wyraźnie inspiruje się dziełami filmowymi. Przykładowo mieszkanie głównego bohatera jest bliźniaczo podobne do kapsuły Korbena Dallasa z filmu Piąty element (The Fifth Element, 1997) w reżyserii Luca Bessona.

${ }^{26}$ Д. Глуховский, Будущее, АСТ, Москва 2013, s. 30-32. 
боко дыша и не сводя глаз с картины за окном. Главное - продержаться пять минут. Шарику нужно ровно столько, чтобы отправить меня в никуда. [...] Они отключают точно на восемь часов, а главное - гарантированно никаких снов. Гениальное изобретение. С ними я буду и безмятежен, и счастлив ${ }^{27}$.

Jest to dla nich jedyna możliwość choćby chwilowego oderwania się od przytłaczającej rzeczywistości.

Dokładnie ten sam mechanizm (choć, co zrozumiałe, jeśli wziąć pod uwagę status materialny, w innym wymiarze) dotyka nieliczną grupkę bogaczy - nieśmiertelność nie jest, jak się okazuje, panaceum na wszelkie problemy człowieka. Przytłaczająca (wzmożona przez wielowymiarową, zależną od kręgu kulturowego „totalitarność” świata) świadomość przeciętnego człowieka, bycia jedynie „śrubką w maszynie" - owszem, potrzebną, ale w razie potrzeby błyskawicznie wymienianą na nową, „niezużytą” - generuje efekt „ślepego zaułka”. W tym kontekście jedynym postulowanym przez autora rozwiązaniem przywracającym ludzkości sens istnienia jest przywrócenie śmierci traktowanej jako akt łaski uwalniający człowieka od koszmaru niekończącego się trwania.

Ciekawym wariantem tego problemu jest wizja zaprezentowana w filmie Мишень (2011) w reżyserii Aleksandra Zeldowicza ${ }^{28}$. Akcja rozgrywa się w stosunkowo niedalekiej przyszłości, w roku 2020. Rosja jest jednym z najbardziej rozwiniętych i bogatych krajów na świecie. Bohaterowie to przedstawiciele bogatej elity społeczeństwa: biznesmeni i popularni prezenterzy telewizyjni - ludzie, w których dostatnie i bezproblemowe życie wkradła się nuda, zniechęcenie i (co najistotniejsze w kontekście naszych rozważań) strach przed śmiercią. W pewnym momencie pojawia się szansa ucieczki przed tym, co nieuchronne - w górach Ałtaju jest stary astrofizyczny kompleks (przez miejscową ludność nazywany „tarcza”), który emituje szczególny rodzaj promieniowania. Ten, kto przyjmie jego dawkę, zatrzyma się w czasie: jego ciało nie tylko przestanie się starzeć, ale wręcz odmłodnieje i ponownie stanie się silne i w pełni sprawne. Życie wieczne ma jednak swoją cenę: jeśli człowiek dotąd wykazywał jakieś negatywne skłonności, ulegał nałogom, miał jakieś wady - wszystko to po „odmłodzeniu" ujawni się z niewyobrażalną siłą. Bohaterowie oczywiście

${ }_{27}$ Tamże, s. 32-33.

${ }^{28}$ Scenariusz: Aleksander Zeldowicz i Władimir Sorokin. Szerzej na ten temat zob.

В. Кичин, Когда время течет вспять. Александр Зельдович и Владимир Сорокин заканчивают фантастический фильм, „Российская Газета”, 15.07.2009, https://rg.ru/2009/o7/15/zeldovitch.html (02.10.2018). 
skwapliwie korzystają z okazji i spędzają noc w reaktorze. Początkowo wszystko wydaje się układać, ale po krótkim okresie euforii, każdy z nich szybko orientuje się, że zmiana dotyczy nie tylko fizyczności, ale i (a może przede wszystkim) sfery wewnętrznej. Wszyscy „napromieniowani” mimowolnie zaczynają eksponować swoje prawdziwe oblicze, wszystko to, co wcześniej skrzętnie ukrywali przed światem. W rezultacie nieśmiertelność staje się dla bohaterów wyrokiem skazującym bez prawa łaski.

W omawianym filmie postęp technologiczny ukazany jest $\mathrm{w}$ tle, jego efekty widać zaledwie w drobnych detalach obrazu świata przedstawionego (np. maska odmładzająca noszona przez jedną z bohaterek), zaś nacisk jest położony na psychologię prezentowanych postaci. Inaczej także jest rozwiązany problem źródła nieśmiertelności - nigdzie nie została wyjaśniona zasada działania tajemniczego reaktora. Jest on integralną częścią rzeczywistości zastanej. Także kwestia nieśmiertelności jest postrzegana niestandardowo nie jako tyle dar, ile wariant ekskluzywnego towaru (przynajmniej w mniemaniu bohaterów), który ma swoją cenę. Nie każdego wbrew pozorom na niego stać, bo okazuje się, że życie wieczne oznacza trwanie w prawdzie bez możliwości odwrócenia tego procesu. W rezultacie problemem staje się nie fakt, że nieśmiertelność, czyli to, co niesamowite, dotąd nieosiągalne, nagle stało się „samowitym”, zwykłym, codziennym, pospolitym. Przekleństwem jest jej cena - życie wieczne to nie perspektywa doświadczania nieustannej prostej przyjemności, przyzwolenia na bezkarny hedonizm, lecz brzemię, a nawet (w obliczu niedoskonałości natury ludzkiej) przekleństwo, kara za pychę. Widać to najwyraźniej w finale filmu, w którym wszyscy funkcjonujący według zasady „uproszczonej przyjemności” bohaterowie w końcu przegrywają i giną (także fizycznie - ostatnia kobieta z grupy „nieśmiertelnych” popełnia samobójstwo rzucając się $\mathrm{z}$ wiaduktu pod pociąg).

$\mathrm{W}$ trzech ostatnich utworach (jakkolwiek bardzo różnych pod względem konwencji, a nawet przynależności gatunkowej) widać, że w centrum uwagi autorów znalazło się pytanie o sposób postrzegania nieśmiertelności w kontekście natury przyjemności. Każdy z twórców wskazuje, że przezwyciężenie śmierci (nieistotne w jaki - przypadkowy, czy świadomy - sposób) przypieczętuje koniec ludzkości. Zanika rozróżnienie pojęć: przyjemność i pożądanie ${ }^{29}$, bo czas na re-

${ }^{29}$ Jak wskazuje Paul Martin, aby zgłębić naturę przyjemności, należy uwzględnić rozróżnienie „między przyjemnością a pożądaniem - wrodzoną, mającą biologiczne 
alizację pragnień jest nieograniczony. Ostatecznie zatem, prędzej czy później, dochodzi do postrzeganej dwuaspektowo nudy ${ }^{30}$ (a w końcu klasycznej acedii), której źródło pochodzi nie z otoczenia człowieka, a z jego wnętrza (co najwyraźniej eksponuje Akunin/Czchartiszwili). Dodatkowo zanik różnicy pomiędzy czasem mierzalnym a doświadczanym, czyli (jak podkreśla Jerzy Gołosz) sposobem istnienia rzeczy $^{31}$ sprawi, że pojęcie teraźniejszości się zdeformuje. Skończoność ludzkiego życia (a więc wpisany w życie-bycie w czasie dynamizm) pozwala wypracować mechanizm pozwalający precyzyjnie oddzielać przeszłość, teraźniejszość i przyszłośćc ${ }^{32}$. W momencie, kiedy owego związku zabraknie, ponieważ ludzkość ugrzęźnie na własne życzenie w niekończącym się „teraz”, to jeśli człowiek w porę się nie ocknie ${ }^{33}-$ nuda pochłonie życie.

Przytoczone przykłady autorskich wizji „nieśmiertelnej codzienności” podają w wątpliwość sens pędu ku życiu wiecznemu, uświa-

podstawy różnicę miedzy lubieniem czegoś dlatego, że sprawia nam przyjemność, a chceniem czegoś dlatego, że wzbudza w nas pożądanie”. P. Martin, Seks, narkotyki i czekolada, przeł. A. Dzierzgowska, MUZA SA, Warszawa 2010, s. 6.

${ }^{30}$ Jak podkreśla Agata Stronciwilk, „Nuda posiada różne aspekty: z jednej strony może zostać rozpoznana jako brak - wydarzeń, zmiany, ruchu; z drugiej zaś, może łączyć się z doświadczeniem nadmiaru i przesytu, które powodują specyficzne 'stępienie', 'ochłodzenie' i brak reakcji organizmu na kolejne bodźce. W drugim przypadku nuda ma charakter subwersywny, pojawia się w obrębie działań, które w założeniu miały jej zapobiec. Sytuuje się więc na dwóch końcach skali ludzkiej reakcji na bodźce płynące z otoczenia. Zarówno ich brak, jak i nadmiar, mogą ją wywoływać”. A. Stronciwilk, Nuda jako stosunek człowieka wobec czasu, „Pisma Humanistyczne" 2014, nr 12, s. 85.

${ }^{31}$ Gołosz pisze, że czas - to „dynamiczne istnienie”. Polega ono na tym, że „rzeczy nie tyle statycznie i beztensowo są w każdej chwili czasu, ile staja się (albo też wchodzq $w$ istnienie), niejako 'przenosząc' w sposób ciągły i płynny swoją obecność w kolejne momenty czasu”. J. Gołosz, Upływ czasu i ontologia, Wydawnictwo UJ, Kraków 2011, s. 9.

${ }^{32}$ Jak pisze Hanna Buczyńska-Garewicz, „[...] teraźniejszość pojmowana jako obecność (Anwesenheit) to teraźniejszość czasu trójczłonowego, czasu, w którym wszystkie trzy fazy są równie rzeczywiste i stale uobecniające się przez tę jedność. [...] Żadna chwila nie jest odcięta od 'było' i 'będzie', lecz z nimi istotnościowo związana”. H. Buczyńska-Garewicz, Metafizyczne rozważania o czasie, Universitas, Kraków 2003, s. 45.

${ }^{3} \mathrm{Na}$ kwestię refleksji życiowej w kontekście zjawiska nudy zwracał uwagę choćby Josif Brodski pisząc, że nuda - to „czysty, nie rozrzedzony czas w całej jego powtarzalnej, jałowej, monotonnej okazałości”, który (paradoksalnie) jest bardzo wartościowy, bo jest najlepszym i bodaj jedynym momentem, który pozwala na refleksję nad życiem, pokazuje czym naprawdę jest nieskończony czas i jaka jest jego istota. Zob. J. Brodski, Pochwała nudy, przeł. A. Kołyszko, M. Kłobukowski, ZNAK, Kraków 1996, s. 91. 
damiając, że zwycięstwo nad śmiercią w połączeniu z immanentną w swej istocie niedoskonałością człowieka - to de facto samospełniająca się przepowiednia zagłady ludzkości ${ }^{34}$. Nie zaskakuje zatem fakt, że silnie zaznacza się w nich „myślenie o przyszłości cywilizacji w perspektywie nieuchronnej katastrofy"35. Jednym z wygenerowanych przy tej okazji bardzo niebezpiecznych „skutków ubocznych" jest jakościowo nowa struktura świata. Nie powstaje on na gruzach poprzednich cywilizacji, lecz zostaje w pewnym momencie unieruchomiony w czasie. $\mathrm{W}$ rezultacie naruszenie naturalnego porządku rzeczy nie tylko nie likwiduje „starych” codziennych problemów ludzkości (takich jak choćby przeludnienie czy bieda), ale jeszcze mocniej je utrwala i ukorzenia w nowym wymiarze rzeczywistości. Jest to sytuacja tym bardziej dokuczliwa, że (co można zaobserwować choćby na podstawie lektury noweli Akunina/ Czchartiszwilego i powieści Głuchowskiego), codzienność (nieważne, dostatnia i spokojna czy biedna i pełna zagrożeń) w końcu zaczyna ciążyć poprzez nieobecność czasu.

Reasumując, immanentna dla natury ludzkiej „mentalność utopijna" ${ }^{6}$ (skądinąd w szerokim znaczeniu pożyteczna, gdyż niezbędna do zmiany świata na lepszy i sprawiedliwszy) będzie pchała ludzkość ku ulepszaniu codzienności aż do naruszenia naturalnego porządku rzeczy. $Z$ drugiej strony, jak widać na przykładzie przytoczonych utworów, autorzy nie wykazują nadmiernego zaufania w stosunku do przedstawicieli własnego gatunku i (przynajmniej na razie) są skłonni twierdzić, że człowiek już na tym etapie rozwoju ludzkości

${ }^{34}$ Problem ten jest od dawna nieustannie nośny (zwłaszcza w kontekście ekspansji nowych technologii) na całym świecie zarówno w literaturze, jak i filmie (począwszy od Odysei kosmicznej 2001 (2001: A Space Odyssey, 1968), poprzez Łowce androidów (Blade Runner, 1985), A.I. Sztuczna inteligencja (Artificial Intelligence AI, 2001), trylogię Matrix (The Matrix (1999), The Matrix Reloaded (2003), The Matrix Revolutions (2003), aż choćby po Transcendencję (Transcendence, 2014).

${ }^{35}$ D. Wojtczak, Siódmy krąg piekła. Antyutopia w literaturze i filmie, REBIS, Poznań 1994, s. 7.

${ }^{36}$ Jak podkreśla Leszek Kołakowski, „Co do świadomości utopijnej, to nie ma powodu, aby ona wygasła, albowiem jest częścią życia umysłowego. Podstawowym elementem świadomości utopijnej jest próba stworzenia techniki, za pomocą której osiągniemy powszechne ludzkie braterstwo". Problemem jest zatem nie sam fakt owej świadomości, a wyważenie proporcji tak, by nie w paść w pułapkę kolejnego totalitaryzmu. B. Wildstein, Wiek utopii. Rozmowa z prof. Leszkiem Kolakowskim, „Wprost”, 07.11.1999, https://www.wprost.pl/tygodnik/6967/ Wiek-utopii.html (06.03.2019). 
nie dorósł do własnych wynalazków i pragnieńn ${ }^{37}$, nie ma więc podstaw przypuszczać, że z czasem to się zmieni. Zamiast niebezpiecznie bawić się w Boga, ludzkość powinna wziąć odpowiedzialność za świat już istniejący i pogodzić się z myślą, że nieodłączną częścią naszej codzienności jest śmierć.

\section{REFERENCES}

Akunin, Boris/Chkhartishvili, Grigoriy. Kladbshchenskiye istorii, Moskva: Kolibri, 2006 [Акунин, Борис - Чхартишвили, Григорий. Кладбщенские истории, Москва: КоЛибри, 2006].

Bartlett, Jamie. Ludzie przeciw technologii. Jak Internet zabija demokrację (i jak ją możemy ocalić). Przeł. Umiński, Krzysztof. Katowice: SONIA DRAGA, 2019.

Baumann, Zygmunt. Śmierć i nieśmiertelność. Warszawa: PWN, 1998.

Baumann, Zygmunt. "O sztuce, śmierci i demokracji i o tym jak się one do siebie mają." Teksty Drugie 1998, no. 3(51): 199-216.

Blanchot, Maurice. L'Entretien infini. Paris: Éditions Gallimard, 1959.

Bolanowska, Tamara. "Trudni bohaterowie, trudne powroty, trudne wybory. Kilka uwag o fantastyce socjologicznej." Literatura i Kultura Popularna 2006, t. XIII, Ed. Żabski, Tadeusz. Wrocław: Wydawnictwo Uniwersytetu Wrocławskiego, 2006: 67-92.

Brodski, Josif. Pochwała nudy. Przeł. Kołyszko, Anna. Kłobukowski, Michał. Kraków: ZNAK, 1996.

Buczyńska-Garewicz, Hanna. Metafizyczne rozważania o czasie. Kraków: Universitas, 2003.

Glukhovskiy, Dmitriy. Budushcheye. Moskva: AST, 2013 [Глуховский, Дмитрий. Будущее. Москва: АСТ, 2013].

Gołąbiowski, Łukasz. "Ten portal społecznościowy sprawi,żebędziesz'nieśmiertelny’.” Komputer Świat, 24.08.2015, <https://www.komputerswiat.pl/aktualnosci/internet/ten-portal-spolecznosciowy-sprawi-ze-bedziesz-niesmiertelny/3jhbqn3>

Gołosz, Jerzy. Uphyw czasu i ontologia. Kraków: Wydawnictwo UJ, 2011.

Kichin, Valeriy. "Kogda vremya techet vspyat'. Aleksandr Zel'dovich i Vladimir Sorokin zakanchivayut fantasticheskiy fil'm." Rossiyskaya gazeta, 15.07.2009, $<$ https://rg.ru/2009/o7/15/zeldovitch.html> [Кичин, Валерий. “Когда вре-

${ }^{37}$ Wydaje się zatem, że rację ma Jamie Bartlett, który pisze, że „Demokracja liberalna wykształciła się w czasach analogowych, więc do analogowej rzeczywistości były przystosowane jej główne założenia i narzędzia do zarządzania kryzysem. W epoce cyfrowej, gdy koncepcje mediów, obywatelstwa, sfery publicznej i demokratycznej wspólnoty gwałtownie ewoluują i zmieniają swój sens, demokracja, jaką znamy, nie posiada już zdolności adaptacji. Albo więc demokracja „dogoni” cyfrową zmianę, a odpowiedzialne społeczeństwo w porę wykształci obywatelskie nawyki na miarę nowej epoki, albo czekają nas rządy technokratycznych despotów przy wsparciu aroganckiej kasty innowatorów z Doliny Krzemowej, którzy wejdą w rolę sędziów i kapłanów nowego porządku”. J. Bartlett, Ludzie przeciw technologii. Jak internet zabija demokrację ( ijak ją możemy ocalić),przeł. K. Umiński, SONIA DRAGA, Katowice 2019. 
мя течет вспять. Александр Зельдович и Владимир Сорокин заканчивают фантастический фильм.” Российская газета, 15.07.2009, <https:// rg.ru/2009/07/15/zeldovitch.html>]

Martin, Paul. Seks, narkotyki i czekolada. Przeł. Dzierzgowska, Anna. Warszawa: MUZA SA, 2010.

Mazurkiewicz, Adam. $Z$ problematyki cyberpunku. Literatura - sztuka - kultura. Łódź: Wydawnictwo Uniwersytetu Łódzkiego, 2014.

Oramus, Dominika. O pomieszaniu gatunków. Science fiction a postmodernizm. Warszawa: Trio, 2010.

Pelevin, Viktor. Lyubov' $k$ trem tsukerbrinam. Moskva: Eksmo, 2014 [Пелевин, Виктор. Любовь к трем цукербринам. Москва: Эксмо, 2014]

Scheler, Max. "Śmierć i dalsze życie." In: idem, Cierpienie, śmierć, dalsze życie. Transl. Węgrzecki, Adam. Warszawa: PWN, 1994.

Sorokin, Vladimir. Den' oprichnika. Moskva: Zakharov, 2006 [Сорокин, Владимир. День опричника. Захаров, Москва 2006]

Sorokin, Vladimir. Manaraga, Moskva: AST, 2017 [Сорокин, Владимир. Манарага, Москва: АCT, 2017]

Stoll, Clifford. Krzemowe remedium. Garść rozważań na temat infostrady. Transl. Hornowski, Tomasz. Poznań: REBIS, 2000.

Stronciwilk, Agata. "Nuda jako stosunek człowieka wobec czasu." Pisma Humanistyczne 2014, no. 12: 85-101.

Wildstein, Bronisław. "Wiek utopii. Rozmowa z prof. Leszkiem Kołakowskim." Wprost, 07.11.1999, <https://www.wprost.pl/tygodnik/6967/Wiek-utopii.html>.

Wojtczak, Dariusz, Siódmy krąg piekła. Antyutopia w literaturze i filmie. Poznań: REBIS, 1994.

Zawojski, Piotr. Cyberkultura. Syntopia sztuki, nauki i technologii. Katowice: Wydawnictwo Uniwersytetu Śląskiego, 2018.

Zywert, Aleksandra. "W labiryncie światów umysłu, czyli o 'Hełmie grozy' Wiktora Pielewina.” Rosja w dialogu kultur, t. II, Ed. Żejmo, Bożena. Toruń: Wydawnictwo Naukowe UMK, 2015: 393-401.

Александра Зыверт

ПОВСЕДНЕВНОСТЬ БУДУЩЕГО, ИЛИ ВОПРОС О ВЕЧНОЙ ЖИЗНИ

Р е 3 ю м е

В статье анализируется проблема бессмертия в контексте явления повседневности. В качестве примеров приводятся прежде всего произведения современных русских писателей-фантастов и авторов, которые используют в своем творчестве фантастические мотивы: Владимира Сорокина (День опричника, Сахарный Кремль, Манарага), Виктора Пелевина (Шлем ужаса, Любовь $\kappa$ трём цукербринам), Анны Старобинец (Живущий), Бориса Акунина-Григория Чхартишвили (Хэппи-энд), Дмитрия Глуховского (Будущее), а также фильм Александра Зельдовича (сценарий в соавторстве с Сорокиным) Мишень. Независимо от принятой концепции, все авторы показывают, что бессмертие - это по многим причинам проклятие человечества. Вместо попыток стать Богом, люди должны сосредоточиться на том, чтобы не потеряться в уже существующей реальности. 


\section{CODZIENNOŚĆ PRZYSZŁOŚCI...}

Aleksandra Zywert

EVERYDAY LIFE OF THE FUTURE OR THE QUESTION OF ETERNAL LIFE

Summary

The paper aims at analyzing the question of immortality in the context of everyday life. The exemplary works include the ones written by contemporary Russian fantasy and science fiction authors, who deploy the relevant motifs: Vladimir Sorokin (Day of the Oprichnik, Kremlin Made of Sugar, Manaraga), Viktor Pelevin (The Helmet of Horror, Love for three Zuckerbrins), Anna Starobinets (The Living), Boris Akunin (Happy end), Dmitry Glukhovsky (The Future) and the film of Alexander Zeldovich (and Sorokin as the scriptwriter) entitled Target. Regardless of the applied convention the authors indicate that immortality is a curse for humankind for many reasons. Instead of trying to become God human beings should focus on retaining the already existing reality. 